\title{
Article \\ Functional Food Product Based on Nanoselenium-Enriched Lactobacillus casei against Cadmium Kidney Toxicity
}

\author{
Simona Ioana Vicas ${ }^{1,+}$, Vasile Laslo ${ }^{1,+}$, Adrian Vasile Timar ${ }^{1,+}$, Cornel Balta ${ }^{2,+}$, Hildegard Herman ${ }^{2,+}{ }^{+}$, \\ Alina Ciceu ${ }^{2,+} \mathbb{D}$, Sami Gharbia ${ }^{2,+}$, Marcel Rosu ${ }^{2,+}$, Bianca Mladin ${ }^{2,+}$, Luminita Fritea ${ }^{3,+}$, Simona Cavalu ${ }^{3,+}+\mathbb{D}$, \\ Coralia Cotoraci ${ }^{4,+}$, József Prokisch ${ }^{5,+}$, Maria Puschita ${ }^{4,+}+\mathbb{D}$, Calin Pop ${ }^{4,+}$, Eftimie Miutescu $^{4,+}$ and \\ Anca Hermenean $2,4, *,+[\mathbb{C}$
}

\section{check for} updates

Citation: Vicas, S.I.; Laslo, V.; Timar, A.V.; Balta, C.; Herman, H.; Ciceu, A.; Gharbia, S.; Rosu, M.; Mladin, B.; Fritea, L.; et al. Functional Food Product Based on NanoseleniumEnriched Lactobacillus casei against Cadmium Kidney Toxicity. Appl. Sci. 2021, 11, 4220. https://doi.org/ 10.3390/app11094220

Academic Editor:

Wojciech Kolanowski

Received: 2 April 2021

Accepted: 30 April 2021

Published: 6 May 2021

Publisher's Note: MDPI stays neutral with regard to jurisdictional claims in published maps and institutional affiliations.

Copyright: (c) 2021 by the authors Licensee MDPI, Basel, Switzerland. This article is an open access article distributed under the terms and conditions of the Creative Commons Attribution (CC BY) license (https:// creativecommons.org/licenses/by/ $4.0 /)$.
1 Faculty of Environmental Sciences, University of Oradea, 410048 Oradea, Romania; svicas@uoradea.ro (S.I.V.); vlaslo@uoradea.ro (V.L.); atimar@uoradea.ro (A.V.T.)

2 "AurelArdelean" Institute of Life Sciences, Vasile Goldis Western University of Arad, 310414 Arad, Romania; baltacornel@gmail.com (C.B.); hildegard.i.herman@gmail.com (H.H.); alinaciceu80@gmail.com (A.C.); samithgh2@hotmail.com (S.G.); ramrosu@gmail.com (M.R.); biancaonitamaria@gmail.com (B.M.)

3 Faculty of Medicine and Pharmacy, University of Oradea, 410073 Oradea, Romania; fritea_luminita@yahoo.com (L.F.); simona.cavalu@gmail.com (S.C.)

4 Faculty of Medicine, Vasile Goldis Western University of Arad, 310414 Arad, Romania; cotoraci.coralia@uvvg.ro (C.C.); mpuschita@yahoo.com (M.P.); medicbm@yahoo.com (C.P.); miucescu.eftimie@uvvg.ro (E.M.)

5 Institute of Animal Science, Biotechnology and Nature Conservation, Faculty of Agricultural and Food Sciences and Environmental Management, University of Debrecen, 4032 Debrecen, Hungary; jprokisch@agr.unideb.hu

* Correspondence: anca.hermenean@gmail.com

+ All authors contributed equally to this work.

Abstract: This paper demonstrates the ability of a functional food based on probiotics and selenium nanoparticles (SeNPs) to annihilate the toxic effect of cadmium on the kidneys. SeNPs were obtained by eco-friendly method used Lactobacillus casei. The morphological features and size of SeNPS were characterized by Atomic Force Microscopy (AFM) and Dynamic Light Scattering (DLS). Two kind of SeNPs were used, purified and Lacto-SeNPs (LSeNPs), administered by gavage at three concentrations $(0.1,0.2$, and $0.4 \mathrm{mg} / \mathrm{Kg} \mathrm{b.w.)}$ for 30 days in a mouse model of cadmium renal toxicity. The blood marker of renal injury (creatinine) significantly decreased in groups where the mice were treated with both form of SeNPs. The antioxidant capacity of plasma was evaluated by Trolox Equivalent Antioxidant Capacity (TEAC) assay and revealed that SeNPs in co-treatment with Cd, promotes maintaining antioxidant activity at the control level. Histopathological analysis of kidneys demonstrated morphological alteration in the group that received only cadmium and restored after administration of SeNPs or LSeNPs. In addition, immunohistochemical analysis revealed antiapoptotic effects through reduction of pro-apoptotic bax and increasing of anti-apoptotic Bcl-2 protein expressions. Moreover, co-administration of $\mathrm{Cd}$ with SeNPs significantly decreased gene expression of kidneys inflammatory markers (TNF- $\alpha$, IL-6, NF-kB) in a dose dependent manner, with the best results for LSeNPs at highest dose $(0.4 \mathrm{mg} / \mathrm{kg})$. Therefore, the L. casei strain is a potential SeNPsenriched probiotic for application as functional food in the future to annihilate cadmium-induced kidneys toxicity.

Keywords: cadmium; selenium; Lactobacillus casei; kidneys; histology; apoptosis; inflammation; functional food; probiotics

\section{Introduction}

Cadmium $(\mathrm{Cd})$ is a toxic heavy metal and is included by International Agency for Research on Cancer classification as carcinogenic to humans (group I) [1]. The sources of $\mathrm{Cd}$ contamination are industry, where is used as a corrosive reagents, color pigments, 
and especially as batteries, and agriculture where is present as impurity in commercial inorganic fertilizers [1-4].

Cd absorption in the body takes place mainly through respiratory and gastro-intestinal tract (by consumption of contaminated food and water) [5]. In the body, Cd is transported by erythrocytes and albumin in the bloodstream and then accumulated in the kidneys, liver, and gut [6-8]. The critical organ of Cd action is kidneys, where has a lot of cytotoxic and metabolic effects. $\mathrm{Cd}$ is accumulated throughout a lifetime, a dangerous feature because it produces renal and hepatic dysfunction, anemia, and cancer in different organs, including the kidneys $[9,10]$.

After exposure to $\mathrm{Cd}$ through diet, $\mathrm{Cd}$ may be absorbed as complexes with different dietary constituents or with metal-binding protein (metallothionein, MT). MT is cysteinerich protein, with a low molecular weight and has a protective contribution in Cd-induced nephrotoxicity and hepatotoxicity [9,11-13].

The inorganic or organic chelators of heavy metals (calcium or zinc trisodiumdiethylenetriaminepentaacetate; carbodithioates; dimercaprol, etc.) were successfully used in remediation of intoxication with heavy metals [9], but this conventional treatment has several adverse effects such as anemia, mineral deficiency, cardiac arrest, or kidney overload [9]. In the last years, the researchers were focused on probiotics [5,14] and nanoparticles [15] as option for the treatment of heavy metals intoxications. Lactic acid bacteria (LAB) are safe microorganisms (included in GRAS category) and are widely used in food industry to produce especially dairy fermented foods, such as yogurt and cheese, besides fermented vegetables, and meats. In addition, lactic acid bacteria are considered probiotics for human with positive effects on health $[5,16]$. LAB were studied for their ability in removing heavy metals from environment, mainly from contaminated water [17]. Because LAB have negative surface charge, the cations $(\mathrm{Cd}, \mathrm{Pb}$, and $\mathrm{As})$ could be binding at the bacteria surface by ion exchange mechanism $[17,18]$.

Lactobacillus species could include selenium (Se) intracellular in the organic form such as selenocysteine [19]. On the other hand, the research studies demonstrated the ability of Lactobacillus species to convert inorganic form of selenium in nanoparticles [20-22].

Selenium (Se) is an essential trace element for human [23] and in the same time is a contradictory mineral, because at higher level become toxic for the organism, while its deficiency produce several health problems [24]. The World Health Organization has established for Se a value of $70 \mu \mathrm{g}$ /day for the maximum daily intake, considering that doses above $400 \mu \mathrm{g}$ /day may exert toxic actions [25].

The foods, like as meat, cereals, and seafoods are the mainly sources for Se in the human body. The forms of Se include (i) organic such as selenomethionine (in cereals and yeast), selenocysteine (in foods of animal origins); (ii) inorganic, i.e., selenite and selenate (Se in the +4 and +6 oxidation state, respectively), which are present in dietary supplements and water [26,27]; and (iii) elemental SeNPs (in the 0 oxidation state) biosynthesized by different microorganism or plants $[20,28]$.

In this moment, some research study on animals or cell cultures, have investigated and demonstrated that Se supplementation can alleviate the toxic effects generated by $\mathrm{Cd}$ [26], but there are few studies on human populations [29]. Chen et al. [29] investigated the renal effects of chronic co-exposure to high levels of $\mathrm{Cd}$ and Se of subjects from China's Hubei Province by determining the content of metals from blood, urine, and hair along with urine and blood biomarkers. Their results showed that the populations did not show renal tubular or glomerular injury, which is explained by the role of Se in improving $\mathrm{Cd}$ induced nephrotoxicity by activating antioxidant enzymes systems. An effect of selenium (Se) on Cd toxicity was observed in a study of Bangladeshi preschool children, aged 4.4-5.4 years [30]. The measured Cd effects were kidney volume, determined by ultrasonography, and estimated glomerular filtration rate (eGFR) calculated from serum cystatin $C$ levels. Urinary Cd levels were inversely associated with eGFR, especially in girls. A beneficial effect of Se was suggested in a Chinese case-control study that included 240 invasive breast cancer cases and 246 age-matched non-cancer controls [31]. There was a 
2.83-fold increase in breast cancer risk in women with urinary $\mathrm{Cd}$ in the highest tertile and urinary Se in the lowest tertile [31]. The risk of breast cancer was also reduced in women with urinary Se in the middle tertile [31].

Based on the information mentioned above, the authors focused on finding ecofriendly solutions to alleviate the toxic effects of $\mathrm{Cd}$ on kidneys. To date, there are several studies focused on ability of lactic bacteria or different nanoparticles to reduce the toxic effects of heavy metals $[14,32,33]$, whereas only one referred to SeNPs-enriched probiotics in a murine model of Cd-induced renal toxicity [34].

The novelty of our study resulted from the use of endogenous nanoselenium biosynthesizes by lactic acid bacteria (L. casei), in order to provide a possible functional food which is able to alleviate the toxic effect of cadmium on kidneys.

In this study, SeNPs biosynthesis was produced by L. casei and consequently two products were obtained: purified SeNPs (bacteria was removed by acidic hydrolysis) and Lacto-SeNPs (bacteria enriched in SeNPs). These products where further tested in vivo for their ability to alleviate toxic effects induced by cadmium in kidneys. For this purpose, both SeNPs products were administered orally to mice for 30 days at three different concentrations $(0.1,0.2$, and $0.4 \mathrm{mg} / \mathrm{kg}$ b.w.) and the creatinine (CREA), total antioxidant plasma (by TEAC assay), along with the histology, immunohistochemistry for mitochondrial apoptosis markers $(b c l-2, b a x)$, and gene expression of hepatic inflammatory markers (NF-kB, TNF $\alpha$, and IL-6) were analyzed in terms of comparative evaluation of dose-dependent protective activity of SeNPs against cadmium intoxication.

\section{Materials and Methods}

\subsection{Eco-Friendly Biosynthesis and Characterization of SeNPs}

In this work, two nano-selenium forms (purified NanoSelenium called, SeNPs and Lacto-NanoSelenium, called, LSeNPs) were produced according to the patent of Prokisch and Zommara [22].

\subsubsection{Production of Purified NanoSelenium Particles (SeNPs)}

The culture medium was prepared by dissolved $5.5 \mathrm{~g}$ of MRS in $100 \mathrm{~mL}$ distilled water, then boiling for $30 \mathrm{~min}$ at $120^{\circ} \mathrm{C}$. After cooling, in the MRS medium was introduced sodium hydrogen selenite $\left(\mathrm{NaHSeO}_{3}\right)$ in a final concentration of $200 \mathrm{mg} / \mathrm{L}$. For the inoculation, Lactobacillus casei (Lyofast LC4P1, Sacco, Cadorago, Italy) was selected for SeNPs biosynthesis in the anaerobic conditions. The initial $\mathrm{pH}$ of medium was around 7 and become around 4 at the end of fermentation process. The reaction was allowed to start in a fermentation bottle into the shaking incubator at $37^{\circ} \mathrm{C}$ for $48 \mathrm{~h}$ until the specific red color of elemental nano-selenium was achieved (Figure 1a). Then, the medium was centrifugation at $6000 \mathrm{rpm}$, for $15 \mathrm{~min}$ and the pellets were uptake in sterilized distilled water. The mechanism of selenium particles formation is mainly intra-cellular for lactic acid bacteria [20], and to obtain the purified SeNPs, the hydrochloric acid (37\%) was used in order to remove the bacteria cell wall. The acidic hydrolysis takes 5 days at room temperature and then, the bacterial cells were removed from the mixture by centrifugation at $6000 \mathrm{rpm}$, for $15 \mathrm{~min}$, the SeNPs were washed with distillated water followed by repeated centrifugation until its $\mathrm{pH}$ becomes 7. The purified SeNPs were vacuum filtering and freeze-drying. The resulted powder was observed under AFM (Agilent 5500 AFM, Agilent Technologies, Santa Clara, CA, USA), using tapping mode with RTESP tip. For DLS assay (ZEN 3690, Malvern Instruments, Malvern, Worcestershire, UK) and zeta potential measurements, the SeNPs powder were re-suspended in distillated water and sonicated during $10 \mathrm{~min}$ before each measurement to avoid aggregation. 
(a)

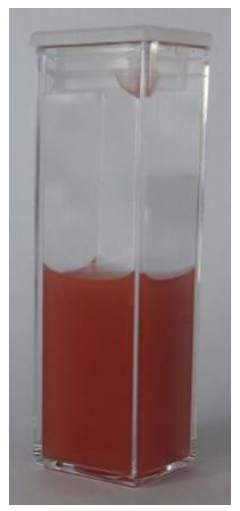

(c)

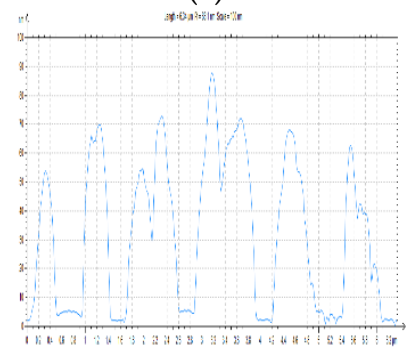

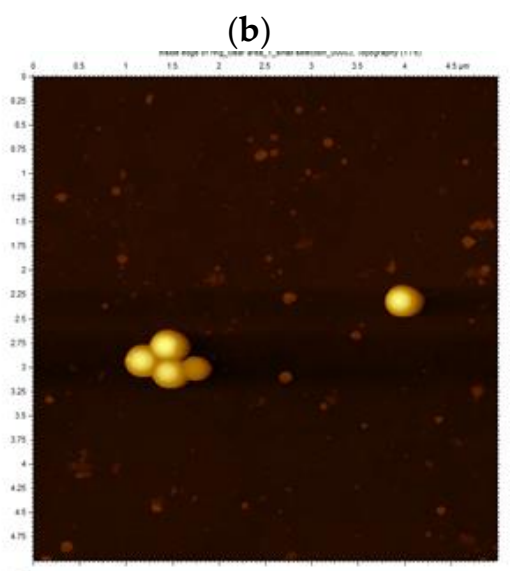

(d)

(e)
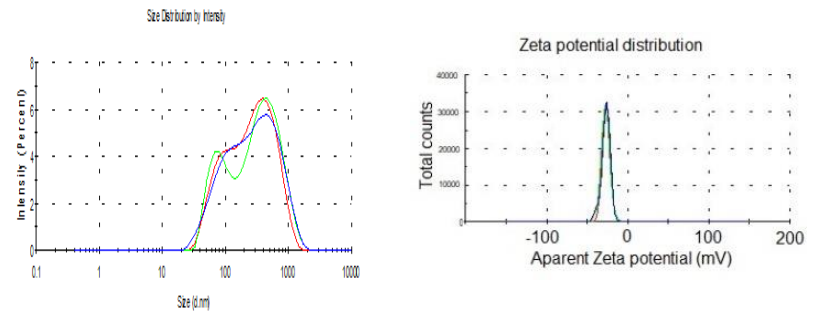

Figure 1. (a). The characteristic red colour of SeNPs. (b). AFM of SeNPs biosynthesized using $L$. casei and $\mathrm{NaHSeO}_{3}$ as a reducing agent. (c). Surface profile of SeNPs recorded from AFM. (d). Size distribution measurement of SeNPs. (e). Apparent Zeta potential records of SeNPs.

\subsubsection{Production of Lacto-NanoSelenium Particles (LSeNPs)}

The production of LSeNPs was performed as described by Eszenyi et al. [20]. The MRS medium was replaced with skimmed milk and sodium hydrogen selenite $\left(\mathrm{NaHSeO}_{3}\right)$ as a reducing agent was used. For the inoculation, Lactobacillus casei (Lyofast LC4P1, Sacco) was selected for LSeNPs biosynthesis in the anaerobic condition. Fermentation took place into the shaking incubator at $37^{\circ} \mathrm{C}$ for $48 \mathrm{~h}$. At the end of fermentation process, the $\mathrm{red} /$ pink yoghurt obtained was centrifuged at $6000 \mathrm{rpm}$ for $15 \mathrm{~min}$ and the solid-phase was freeze-drying in order to obtain the powder of LSeNPs.

\subsection{Animal and Experimental Design}

In the experiment, female CD1 mice ( $26 \pm 3 \mathrm{~g}$ ) from the University's Animal Facility were used, after prior ethical approval of the working protocol by the Ethical Committee of Vasile Goldis Western University of Arad and certification by the National Sanitary Veterinary and Food Safety Authority of Romania (005/27 February 2017). Mice were fed with an autoclavable standard scientific diet for rodents (Safe D40 diet, SAFE Complete Care Competence, Rosenberg, Germany), which is certified free of toxic substances and balanced regarding the content of amino acids, fatty acids, minerals and vitamins.

Mice were randomly assigned to 8 experimental groups $(n=10)$ :

- Control group—received orally by gavage during the experiment only water;

- Cadmium group $(\mathrm{Cd})$-received orally $5 \mathrm{mg} / \mathrm{kg} \mathrm{CdCl} 2$;

- $\quad 0.1$ SeNPs + Cd-received orally by gavage $0.1 \mathrm{mg} / \mathrm{kg}$ of SeNPs together with 5 $\mathrm{mg} / \mathrm{kg}$ of $\mathrm{CdCl}_{2}$

- $\quad 0.2 \mathrm{SeNPs}+\mathrm{Cd}-$ received orally by gavage $0.2 \mathrm{mg} / \mathrm{kg}$ of SeNPs together with $5 \mathrm{mg} / \mathrm{kg}$ of $\mathrm{CdCl}_{2}$

- $\quad 0.4 \mathrm{SeNPs}+\mathrm{Cd}$-received $0.4 \mathrm{mg} / \mathrm{kg}$ of SeNPs together with $5 \mathrm{mg} / \mathrm{kg}$ of $\mathrm{CdCl}_{2}$

- $\quad 0.1 \mathrm{LSeNPs}+\mathrm{Cd}$-received orally by gavage $0.1 \mathrm{mg} / \mathrm{kg}$ of LSeNPs together with $5 \mathrm{mg} / \mathrm{kg}$ of $\mathrm{CdCl}_{2}$ 
- $\quad 0.2 \mathrm{LSeNPs}+\mathrm{Cd}$-received orally by gavage $0.2 \mathrm{mg} / \mathrm{kg}$ of LSeNPs together with $5 \mathrm{mg} / \mathrm{kg}$ of $\mathrm{CdCl}_{2}$

- $\quad 0.4 \mathrm{LSeNPs}+\mathrm{Cd}$-received $0.4 \mathrm{mg} / \mathrm{kg}$ of LSeNPs together with $5 \mathrm{mg} / \mathrm{kg}$ of $\mathrm{CdCl}_{2}$

The three doses of SeNPs $(0.1,0.2$, and $0.4 \mathrm{mg} / \mathrm{kg}$ b.w.) and route of administration were selected according to the results in which protection was obtained against cadmium, administered to mice at a dose of $5 \mathrm{mg} / \mathrm{kg}$ [35].

The administration of NSePs and LNSePs was performed one hour after the administration of $\mathrm{Cd}$. Thirty days after the first oral administration the mice were euthanized under anesthesia with a mixture of ketamine and xylazine. Blood and kidney tissues were collected for further analysis.

\subsection{Blood Creatinine Level}

Venous blood samples were centrifuged at $3500 \mathrm{rpm}$ for $10 \mathrm{~min}$ and then analyzed for creatinine (CREA) level (ChemaDiagnostica, Monsano, Italy) with a Mindray BS-120 Chemistry Analyzer (ShenzenMindray Bio-Medical Electronics Co., Ltd., Nanshan, Shenzhen, China).

\subsection{Antioxidant Capacity of Mice Plasma-TEAC Assay}

The Trolox Equivalent Antioxidant Capacity (TEAC) is one of the methods developed to measure the total antioxidant capacity of mice plasma and was performed using modified method of Re et al., 1999 [36]. Shortly, ABTS (2,2'-azinobis (3-ethylbenzothiazoline6-sulfonic acid) diammonium salt) was dissolved in PBS, pH 7.4 to obtained a $7 \mathrm{mM}$ concentration. The radical cation of $\mathrm{ABTS}^{\bullet+}$ solution was produced by reacting with $2.45 \mathrm{mM}$ potassium persulfate, in the dark, at room temperature, overnight $(16 \mathrm{~h})$ before use. Before analysis, the radical cation of $\mathrm{ABTS}^{\bullet+}$ solution was diluted with PBS, at $\mathrm{pH}$ 7.4 in order to obtain an absorbance of $0.70 \pm 0.02$ at $734 \mathrm{~nm}$. After addition of $10 \mu \mathrm{L}$ of plasma or Trolox standard (final concentration $0-25 \mu \mathrm{M}$ ) to $1 \mathrm{~mL}$ of diluted ABTS ${ }^{\bullet+}$, the absorbance was reading exactly $1 \mathrm{~min}$ after initial mixing. The results were expressed as percentage inhibition of radical cation of $\mathrm{ABTS}^{\bullet+}$.

\subsection{Histopathology Analysis}

Kidney samples were fixed in $4 \%$ paraformaldehyde solution in PBS for $24 \mathrm{~h}$, followed by dehydration in a graded series of ethanol, clarified in toluene, following by paraffin embedding. Sections of $5 \mu \mathrm{m}$ were stained with hematoxylin-eosin (H\&E) and examined under an Olympus BX43 light microscope (Tokyo, Japan) and images captured using an XC30 CCD camera (Tokyo, Japan).

\subsection{Immunohistochemical Analysis}

Kidney paraffin embedded sections were deparaffinized in Dewax (Biosystems, Nussloch, Germany) and rehydrated prior to epitope retrieval in Novocastra sol. (Leica Biosystems, Nussloch, Germany). Following neutralization of endogenous peroxidase, sections were incubated overnight at $4{ }^{\circ} \mathrm{C}$ with anti bax and $b c l-2$ antibodies (1:100) (Santa Cruz, Dallas, TX, USA). Detection was then performed using a polymer detection system (cat. no. RE7280 K; Novolink Max Polymer Detection system) and 3,3'diaminobenzidine (DAB) as chromogenic substrate. Nuclei were stained with hematoxylin. Slides were mounted and examined under an Olympus BX43 light microscope.

\subsection{RT-PCR Analysis}

Kidney samples collected on RNAlater (Thermo Fisher Scientific, USA) were stored at $-80{ }^{\circ} \mathrm{C}$ until processing. The RNA extraction was performed with SV Total RNA Isolation System extraction kit (Promega, Madison, WI, USA), according to the manufacturer's recommendations. The quantitative and qualitative analysis of RNA was assessed by spectrophotometry (NanoDrop 8000, Thermo Fisher Scientific, Waltham, MA, USA). For Real Time PCR, the LuminarisHiGreenqPCT Master Mix kit (Thermo Scientific, Waltham, 
MA, USA) and Applied Biosystems 7500 Real Time PCR System (Foster City, CA, USA) were used. Samples were tested in triplicate and the glyceraldehyde 3-phosphate dehydrogenase $(\mathrm{GAPDH})$ gene was used as reference. Primers used were included in Table 1 . The results obtained were interpreted using the $2 \Delta \Delta C T$ method of Livak et al., 2001 [37].

Table 1. Primer sequences for RT-PCR.

\begin{tabular}{|c|c|c|}
\hline Target & Sense & Antisense \\
\hline NF-kB 65 & 5'CTTGGCAACAGCACAGACC3' & 5'GAGAAGTCCATGTCCGCAAT3' \\
\hline TNF- $\alpha$ & 5'CTGTAGCCCACGTCGTAGC3' & 5'TTGAGATCCATGCCGTTG3' \\
\hline IL-6 & 5' AAAGAGTTGTGCAATGGCAATTCT3' & 5'AAGTGCATCATCGTTGTTCATACA3' \\
\hline GAPDH & 5'CGACTTCAACAGCAACTCССАСТСТТСС $3^{\prime}$ & 5'TGGGTGGTCCAGGGTTTCTTACTCCTT3' \\
\hline
\end{tabular}

\subsection{Statistical Analysis}

All values represent mean \pm standard deviation (SD) for 10 mice in each group, and statistically significant differences $\left({ }^{*} p<0.05 ;{ }^{* *} p<0.01 ;{ }^{* * *} p<0.001\right.$ and \#\#\# $\left.p<0.001\right)$ were determined compared with control and cadmium group $(\mathrm{Cd})$, respectively. Data were statistically processed using GraphPad Prism 3.03 software (GraphPad Software, Inc., La Jolla, CA, USA), and one-way analysis of variance, followed by a Bonferroni's Multiple Comparison Test.

\section{Results and Discussion}

\subsection{Physico-Chemical Characterization of SeNPs}

The appearance of red colour (Figure 1a) suggest the formation of elemental nanoselenium, which has been confirmed by us through AFM and DLS.

As evidenced by AFM image (Figure 1b), regular, spherical shape, Se nanoparticles were obtained by eco-friendly synthesis. The DLS measurements (Figure 1c) revealed two maximum size distributions: first one with average size of $90 \mathrm{~nm}$ and lower concentration, and second one, with average size of about $400 \mathrm{~nm}$ and higher concentration. Even SeNPs tends to aggregate into larger size spheres (including at room temperature) due to their high surface to volume ratio, we were able to identify single nanoparticles, well distributed on the mica-support surface, without any aggregation. Moreover, the size of SeNPs obtained by DLS assay was in line with the observed AFM details. The zeta potential measurements (Figure 1d) indicates $-26.6 \mathrm{mV}$, which is considered an indicative for good stability, according to the literature [38]. It is well known that the criteria of stability of NPs are measured when the values of zeta potential ranged from higher than $+20 \mathrm{mV}$ to lower than $-20 \mathrm{mV}$ [39].

Different microorganisms are able to reduce inorganic selenium into red elemental SeNPs in different size with an unique structured nanospheres with regular and uniform size $[20,22,39]$. According to previous our work [20] selenium in the LSeNPS is manly $(>95 \%)$ in a form of nanoselenium and the rest $(<5 \%)$ is organic selenium.

Xu et al. [40], demonstrated that probiotic L. casei 393 is able to transform sodium selenite to SeNPs under anaerobic conditions which is considered to be one of the mechanism of Se detoxification. Three different ways were proposed to explain the bioconversion of Se from +4 to 0 oxidation state [40]: (i) the periplasmic nitrite reductase (nitrite reductase, sulfite reductase, and GSH reductase); (ii) redox precipitation of both elemental sulfur and elemental Se; and (iii) a glutathione reductase catalyzes the reaction of GSH with $\mathrm{Se}+4$ to produce GS-Se-SG, further generate GS-Se.

\subsection{Effect of SeNPs on Blood Creatinine Level}

The results of CREA are shown in Figure 2. The level of CREA is used as an indicator of renal function [41]. The blood CREA level increases after Cd administration by $17 \%$, but the treatment with SeNPs in both forms (purified and LSeNPs) significantly decreased the level of this indicator except for the group were the lowest dose of SeNPs was used 
(0.1 mg/kg). The lowest CREA levels was recorded for the $0.2 \mathrm{mg} / \mathrm{kg}$ of LSeNPs group, demonstrated the good efficiency of LSeNPs to annihilate the Cd-induced renal toxic effect.

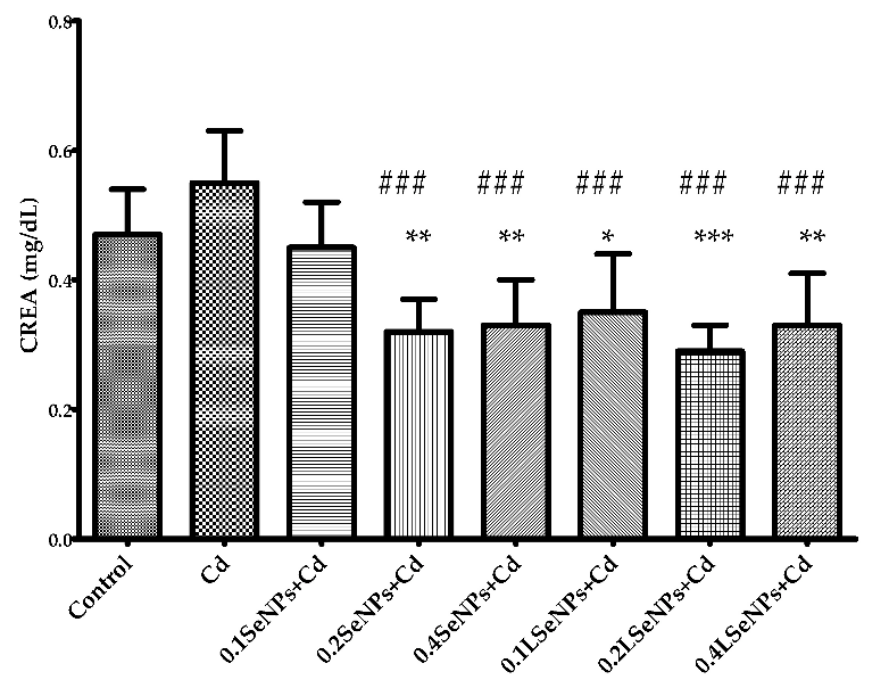

Figure 2. Effects of cadmium and both form of selenium (SeNPs, purified and LSeNPs) on CREA level and LDH activity after 30 days treatments. All values were expressed as mean \pm SD for 10 mice in each group. Groups: Control-mice received only water; Cadmium group (Cd)-mice received orally $5 \mathrm{mg} / \mathrm{kg} \mathrm{CdCl} 2 ; 0.1 \mathrm{SeNPs}+\mathrm{Cd}(0.1 \mathrm{mg} / \mathrm{kg} \mathrm{SeNPs}+5 \mathrm{mg} / \mathrm{kg} \mathrm{CdCl}) ; 0.2 \mathrm{SeNPs}+\mathrm{Cd}(0.2 \mathrm{mg} / \mathrm{kg}$ SeNPs $+5 \mathrm{mg} / \mathrm{kg} \mathrm{CdCl} 2) ; 0.4 \mathrm{SeNPs}+\mathrm{Cd}(0.4 \mathrm{mg} / \mathrm{kg}$ SeNPs $+5 \mathrm{mg} / \mathrm{kg} \mathrm{CdCl} 2) ; 0.1 \mathrm{LSeNPs}+\mathrm{Cd}$ $\left.(0.1 \mathrm{mg} / \mathrm{kg} \text { LSeNPs }+5 \mathrm{mg} / \mathrm{kg} \mathrm{CdCl})_{2}\right) ; 0.2 \mathrm{LSeNPs}+\mathrm{Cd}(0.2 \mathrm{mg} / \mathrm{kg} \mathrm{LSeNPs}+5 \mathrm{mg} / \mathrm{kg} \mathrm{CdCl} 2) ;$ $0.4 \mathrm{LSeNPs}+\mathrm{Cd}(0.4 \mathrm{mg} / \mathrm{kg}$ LSeNPs $+5 \mathrm{mg} / \mathrm{kg} \mathrm{CdCl})$. Groups: SeNPs $+\mathrm{Cd}$ and LSeNPs $+\mathrm{Cd}$ at different concentration vs. control group: ${ }^{*} p<0.05 ;{ }^{* *} p<0.01 ;{ }^{* *} p<0.001$. Groups: SeNPs $+\mathrm{Cd}$ and LSeNPs + Cd at different concentration vs. cadmium group (Cd): \#\# $p<0.001$.

No significant differences were observed in CREA level when the male SpragueDawley rats were administrated gavage SeNPs at levels between 0.2 and $8.0 \mathrm{mg} / \mathrm{kg}$ body weight, demonstrating that SeNPs were not toxic at the concentrations tested [42]. In other study, the CREA levels were higher in male albino rats group that receive $\mathrm{Cd}$ compared with the control group, instead not significantly changes were recorded in Se treated group alone or $\mathrm{Cd}+$ Se treated group compared with control group [23].

\subsection{Antioxidant Capacity of Mice Plasma-TEAC Assay}

The most commonly methods used for assessing total antioxidant capacity of plasma or serum are FRAP (Ferric Reducing Antioxidant Power) and TEAC (Trolox Equivalent Antioxidant Capacity). The mechanisms of measuring antioxidant capacity are different in these methods. For examples, FRAP assay measures the iron reducing ability of biological sample [43], while TEAC assay is based on inhibition of radical cation ABTS ${ }^{\bullet+}\left(2,2^{\prime}\right.$-azinobis (3-ethylbenzothiazoline 6-sulfonate) inhibition [44].

Antioxidant capacity of mice plasma was evaluated using TEAC assay, where potassium persulfate as radical-initiator of ABTS was used. The concentration-response curve of different Trolox solutions (0.25-2 mM) is shown in Figure 3a. The TEAC values of mice plasma, expressed as \% inhibition of ABTS is shown in Figure 3b. Our results revealed significant decrease in the antioxidant capacity of mice plasma for $\mathrm{Cd}$ group, while $\mathrm{Cd}$ co-treatments with SeNPs did not affect the antioxidant capacity compared to the control group, suggesting selenium protection. 


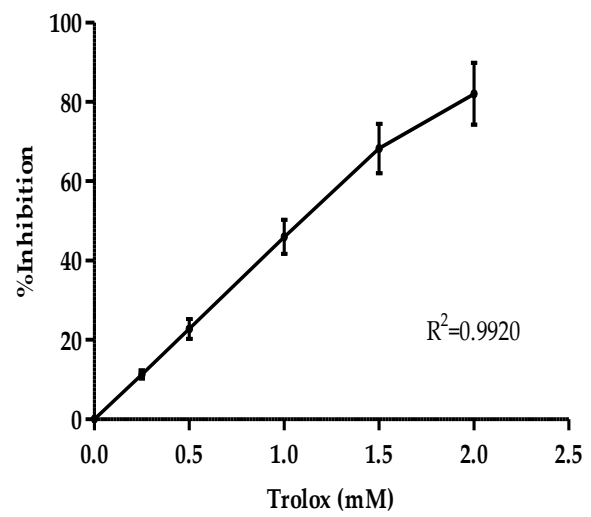

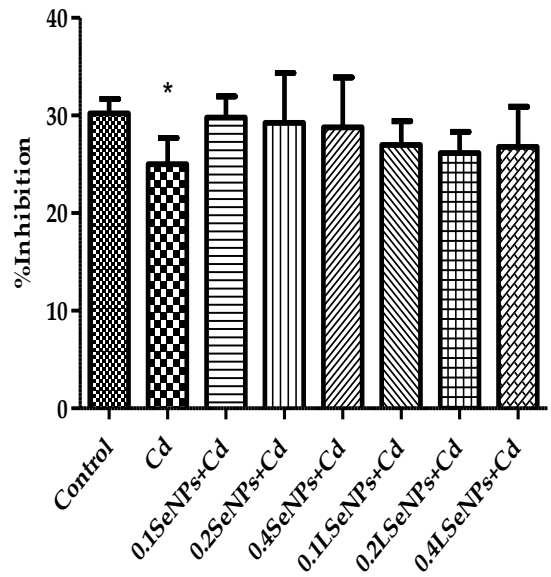

Figure 3. (a). Trolox concentrations-response curve of $\%$ Inhibition of ABTS ${ }^{\bullet+}$, recorded at $734 \mathrm{~nm}$. Five different standard concentrations (between 0.25 and $2 \mathrm{mM}$ Trolox) were used in triplicate. (b).The \% Inhibition of $\mathrm{ABTS}^{\bullet+}$ from blood mice after 30 days treatments. All values were expressed as mean $\pm \mathrm{SD}$ for 10 mice in each group. Statistically significant difference at ${ }^{*} p<0.05$. Groups: Control-mice received only water; Cadmium group (Cd)-mice received orally $5 \mathrm{mg} / \mathrm{kg} \mathrm{CdCl}$; $0.1 \mathrm{SeNPs}+\mathrm{Cd}(0.1 \mathrm{mg} / \mathrm{kg} \mathrm{SeNPs}+5 \mathrm{mg} / \mathrm{kg} \mathrm{CdCl} 2) ; 0.2 \mathrm{SeNPs}+\mathrm{Cd}(0.2 \mathrm{mg} / \mathrm{kg} \mathrm{SeNPs}+5 \mathrm{mg} / \mathrm{kg}$ $\left.\mathrm{CdCl}_{2}\right) ; 0.4 \mathrm{SeNPs}+\mathrm{Cd}(0.4 \mathrm{mg} / \mathrm{kg}$ SeNPs $+5 \mathrm{mg} / \mathrm{kg} \mathrm{CdCl} 2) ; 0.1 \mathrm{LSeNPs}+\mathrm{Cd}(0.1 \mathrm{mg} / \mathrm{kg} \mathrm{LSeNPs}$ $+5 \mathrm{mg} / \mathrm{kg} \mathrm{CdCl} 2) ; 0.2 \mathrm{LSeNPs}+\mathrm{Cd}(0.2 \mathrm{mg} / \mathrm{kg} \mathrm{LSeNPs}+5 \mathrm{mg} / \mathrm{kg} \mathrm{CdCl} 2) ; 0.4 \mathrm{LSeNPs}+\mathrm{Cd}$ $(0.4 \mathrm{mg} / \mathrm{kg} \text { LSeNPs }+5 \mathrm{mg} / \mathrm{kg} \mathrm{CdCl})_{2}$.

Total antioxidant capacity depending on the chemical reactions involved can be classified into two classes: hydrogen atom transfer and on single electron transfer methods. The TEAC assay is part of the last method, where the mechanism is based on the ability of a sample to transfer one electron to reduce radicals. The ABTS radical is soluble in both aqueous and organic solvent which allows the simultaneous evaluation of hydrophilic and lipophilic compounds being one of the advantages of TEAC method [43].

Cadmium is unable to generate directly free radicals, but superoxide radical, hydroxyl radical could be generated indirectly [9]. The studies on animals shown the acute intoxication with cadmium increased antioxidant defense enzymes, including catalase, glutathione peroxidase, glutathione-S-transferase and superoxide dismutase $[1,9,45]$. Our results shows that both form of SeNPs were able to counteract the oxidative stress effects of $\mathrm{Cd}$. Se antagonizes the toxicity of $\mathrm{Cd}$ through the action of Se-dependent antioxidant enzymes such as glutathione peroxidase and thioredoxin reductase [26]. Moreover, it is known that selenium pretreatment of rats intoxicated with cadmium led to a significant decrease in MDA concentration, and increased levels of glutathione (GSH) and glutathione peroxidase (GPx) and thioredoxin reductase (TrxR) activities, when compared with those of cadmium-treated group; by this enzymatic mechanism it reduces the renal lipid peroxidation and induced a significant restoring of the antioxidant system affected by cadmium administration [46]. In humans (controlled trial study) selenium might reduce the oxidative stress by increasing total antioxidant capacity (TAC) and glutathione peroxidase (GPX) levels and decreasing serum malonaldehyde (MDA), both of which being crucial factors for reduction of oxidative stress [47].

\subsection{Histopathology Analysis}

Light microscopic examination showed a normal structure of the kidney (Figure 4a) in the controls. Glomerular atrophy, tubular necrosis and widening were evident in the kidneys of all Cd-exposed animals (Figure $4 \mathrm{~b}$ ). Simultaneous administration of SeNPs with $\mathrm{Cd}$, reduced the heavy metal toxic structural changes in the kidney in dose dependent manner. The kidney morphology of the LSeNPs-Cd groups did not differ from that of 
the control animals, offering a complete prevention from the $\mathrm{Cd}$-induced changes in renal structure at highest dose (Figure $4 \mathrm{~h}$ ).
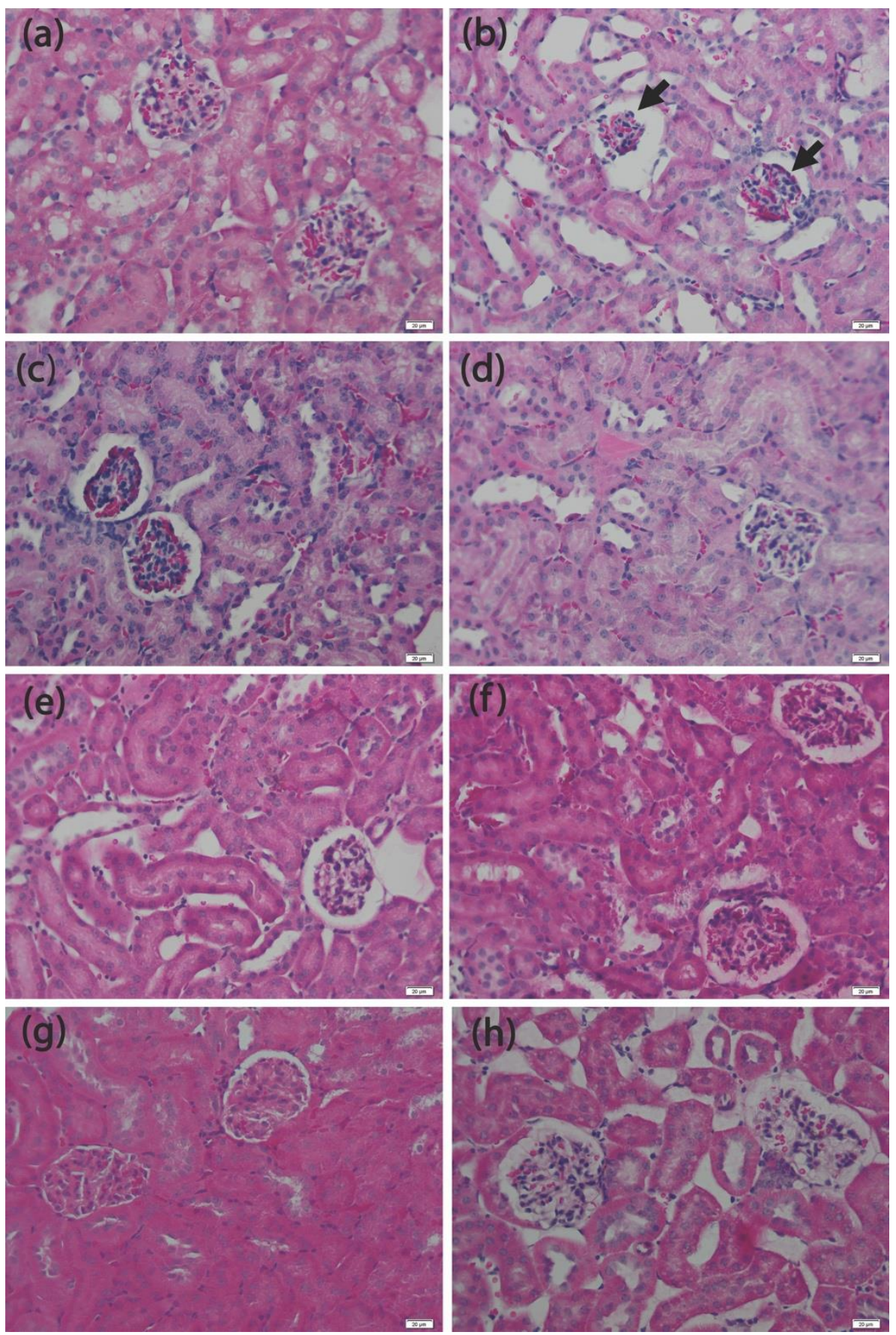

Figure 4. Histopathological sections of kidney of the experimental groups, $H \& E \times 200$. Various degrees of histopathological changes were observed in Cd exposure groups, mainly including glomerular atrophy (arrow) and tubular damage (b). Co-administration of SeNPs with Cd, reduced the metal toxic histological changes in the kidney in dose dependent manner, more obvious for LSeNPs. CV-centrilobular vein. Groups: Control (a)-mice received only water; Cadmium group (b)-mice received orally $5 \mathrm{mg} / \mathrm{kg} \mathrm{CdCl} 2 ; 0.1 \mathrm{SeNPs}+\mathrm{Cd}$ (c) $(0.1 \mathrm{mg} / \mathrm{kg} \mathrm{SeNPs}+5 \mathrm{mg} / \mathrm{kg} \mathrm{CdCl} 2)$; $0.2 \mathrm{SeNPs}+\mathrm{Cd}(\mathrm{d})(0.2 \mathrm{mg} / \mathrm{kg}$ SeNPs $+5 \mathrm{mg} / \mathrm{kg} \mathrm{CdCl}) ; 0.4 \mathrm{SeNPs}+\mathrm{Cd}(\mathbf{e})(0.4 \mathrm{mg} / \mathrm{kg} \mathrm{SeNPs}+$ $5 \mathrm{mg} / \mathrm{kg} \mathrm{CdCl} 2) ; 0.1 \mathrm{LSeNPs}+\mathrm{Cd}(\mathbf{f})(0.1 \mathrm{mg} / \mathrm{kg} \mathrm{LSeNPs}+5 \mathrm{mg} / \mathrm{kg} \mathrm{CdCl} 2) ; 0.2 \mathrm{LSeNPs}+\mathrm{Cd}(\mathrm{g})$ $(0.2 \mathrm{mg} / \mathrm{kg}$ LSeNPs $+5 \mathrm{mg} / \mathrm{kg} \mathrm{CdCl} 2) ; 0.4 \mathrm{LSeNPs}+\mathrm{Cd}(\mathbf{h})(0.4 \mathrm{mg} / \mathrm{kg}$ LSeNPs $+5 \mathrm{mg} / \mathrm{kg} \mathrm{CdCl})$. 
Several histopathological studies revealed that the toxic effects of $\mathrm{Cd}$ in the kidney are confined with proximal tubular cells, affected by necrosis and apoptosis and tubular degeneration [48-50]. Early tubular disease in Cd nephrotoxicity [51] and tubular proteinuria continued with glomerular damage, leading to albuminuria and a progressive impairment in glomerular filtration, are injuries induced by cadmium, causing end-stage renal failure [52]. In our experiment we noticed several histopathological renal changes, including both of tubular injuries and glomerular atrophy or swelling, which are in agreement with previous toxicological results, suggesting that exposure to $\mathrm{Cd} 5 \mathrm{mg} / \mathrm{kg}$ to mice induced morpho-functional changes and renal dysfunction.

$\mathrm{Cd}$ is absorbed from the gastrointestinal tract into the circulation by a transporter, DMT1 (Divalent Metal Ion Transporter 1), in the duodenum [53]. Once it reaches the liver it is rapidly bound to metallothionein (MT), which is then slowly released back into circulation. The Cd-MT complex is filtered at the glomerulus and reabsorbed by the proximal tubule, being a protective response to limit toxicity from free $\mathrm{Cd}\left(\mathrm{Cd}^{2+}\right)$. Unfortunately, once the MT-producing capacity of proximal renal tubular cells is exhausted, progressive tubular cell damage occurs and the intracellular levels of $\mathrm{Cd}^{2+}$ increase [54]. Cd can also induce autoantibodies to MT, which may be toxic for tubular cells and interfere with $\mathrm{Cd}$ detoxification [55], while other autoantibodies target induced glomerular damage [51], and manifested by morphological changes on both tubular and glomerular cells. In our experiments, a dose-dependent increase protection against nephrotoxicity induced by cadmium was obtained with the highest dose of LSeNPs, which might be associated with redox regulatory effect of Se, showed by recovery of glutathione peroxidase and thioredoxin reductase activities, decreasing free radical-mediated lipid peroxidation and glutathione regeneration [56].

\subsection{The SeNPs Prevent Apoptosis in Renal Parenchyma Induced by Cadmium}

The $B c l-2$ family proteins play a crucial role for the mitochondria dependent apoptotic pathway [57]. Bcl-2 is known as an anti-apoptotic protein which protects the cells from apoptosis, whereas the pro-apoptotic proteins such as Bax promote the programmed cell death.

Exposure to $\mathrm{Cd}$ causes the activation of apoptosis-related mitochondrial signaling and DNA damage response [58], through unbalancing $B c l-2 / B a x$ ratio which determines cell death [59], and considering a valuable tool to assess renal protective effects of SeNPs and LSeNPs against the pro-apoptotic activity of Cd.

As shown in Figure 5, Cd exposure increased immunopositivity of pro-apoptotic Bax protein, especially at tubular level and decreased expression of anti-apoptotic $B c l-2$ protein, however, co-treatment with SeNPs and LSeNPs induced a marked reduction in positivity of Bax and increased Bcl-2 protein positivity in a dose-dependent manner.

Mitochondria is the major intracellular target for $\mathrm{Cd}$ toxicity, inhibiting directly $\mathrm{Na} / \mathrm{K}$ pump [60]; accumulation of $\mathrm{Cd}^{2+}$ is followed by inhibition of the respiratory chain by acting at the level of complex III [61] and resulting in the generation of reactive oxygen species (ROS) [62], and mitochondrial damage [63] with release of cytochrome c [64], leading to caspase activation, causing cell death by apoptosis and necrosis [65-67]. Moreover, previous studies showed that exposure to $\mathrm{Cd}$ down-regulated anti-apoptotic $\mathrm{Bcl}-2$ protein and upregulated pro-apoptotic Bax protein, suggesting that $C d$-induced apoptosis via regulations of $B c l-2$ and $B a x$, while selenium has an ability to inhibit mitochondrial apoptotic pathway in oxidative stress mediated kidney dysfunction caused by cadmium and rebalanced the $\mathrm{Bcl}-2$ / Bax ratio [68], as we showed in our experiment. 


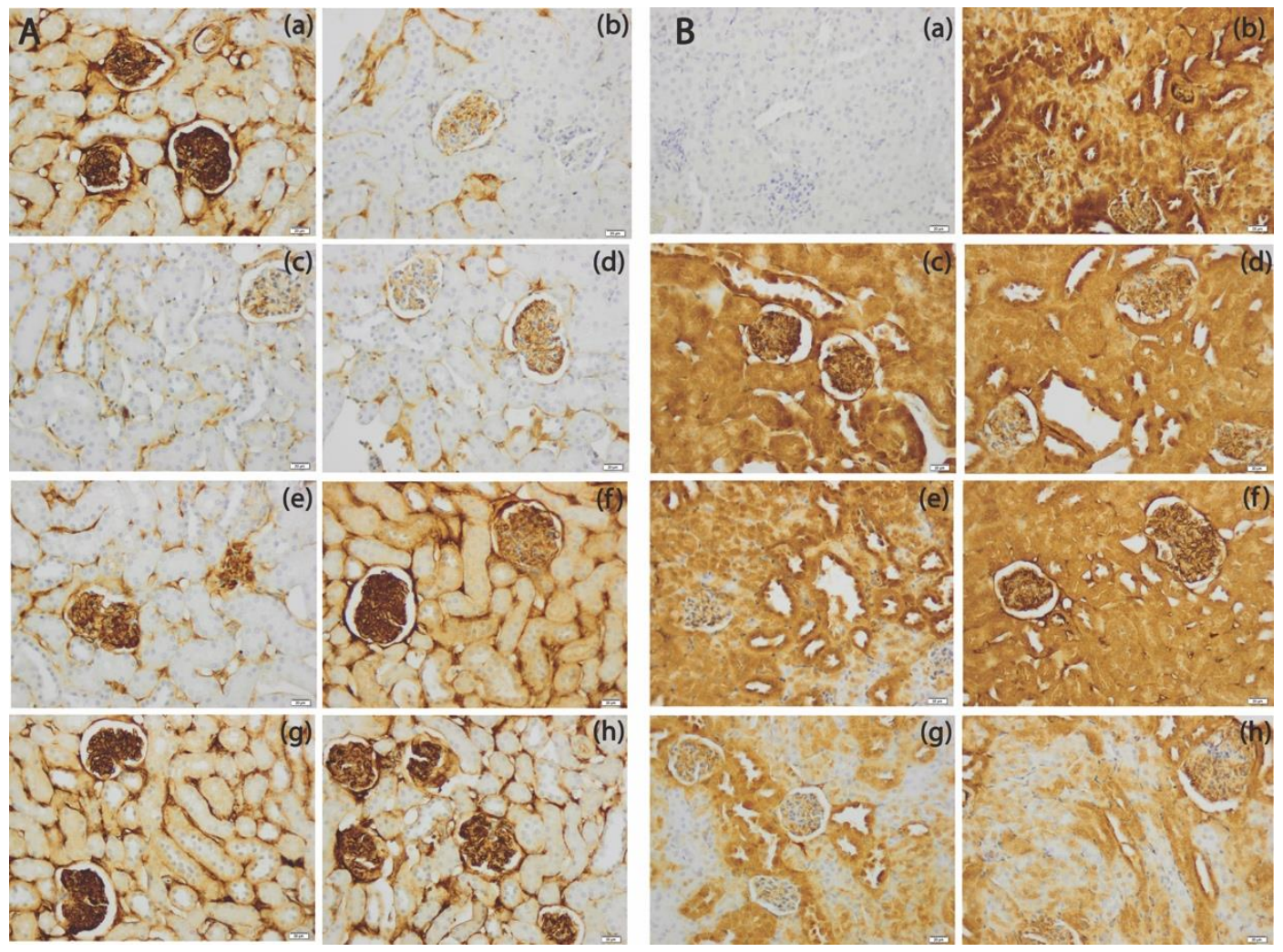

Figure 5. Renal immunohistochemical expression of Bcl-2 (A) and Bax (B) in: Groups: Control (a)-mice received only water; Cadmium group (b)-mice received orally $5 \mathrm{mg} / \mathrm{kg} \mathrm{CdCl} 2 ; 0.1 \mathrm{SeNPs}+\mathrm{Cd}$ (c) $(0.1 \mathrm{mg} / \mathrm{kg} \mathrm{SeNPs}+5 \mathrm{mg} / \mathrm{kg} \mathrm{CdCl} 2)$; $0.2 \mathrm{SeNPs}+\mathrm{Cd}(\mathbf{d})(0.2 \mathrm{mg} / \mathrm{kg} \mathrm{SeNPs}+5 \mathrm{mg} / \mathrm{kg} \mathrm{CdCl}) ; 0.4 \mathrm{SeNPs}+\mathrm{Cd}(\mathbf{e})\left(0.4 \mathrm{mg} / \mathrm{kg} \mathrm{SeNPs}+5 \mathrm{mg} / \mathrm{kg} \mathrm{CdCl}_{2}\right) ;$ $0.1 \mathrm{LSeNPs}+\mathrm{Cd}(\mathbf{f})(0.1 \mathrm{mg} / \mathrm{kg}$ LSeNPs$+5 \mathrm{mg} / \mathrm{kg} \mathrm{CdCl} 2) ; 0.2 \mathrm{LSeNPs}+\mathrm{Cd}(\mathrm{g})(0.2 \mathrm{mg} / \mathrm{kg} \mathrm{LSeNPs}+5 \mathrm{mg} / \mathrm{kg} \mathrm{CdCl}) ;$ $0.4 \mathrm{LSeNPs}+\mathrm{Cd}(\mathrm{h})(0.4 \mathrm{mg} / \mathrm{kg}$ LSeNPs $+5 \mathrm{mg} / \mathrm{kg} \mathrm{CdCl})$.

\subsection{The SeNPs Prevent Inflammation in Kidney Parenchyma Induced by Cadmium}

Central events in Cd-induced tissue injury include generation of reactive oxygen species, and inflammation with increased production of proinflammatory cytokines leading to renal tissue damage $[26,64,69,70]$

As shown in Figure 6, Cd exposure up-regulated TNF- $\alpha$, IL-6, NF-kB, however, co-treatment with SeNPs induced their down-regulation in a dose-dependent manner, highlighted for LSeNPs at highest dose.

In our study we demonstrate that $\mathrm{Cd}$-induced nephrotoxicity is associated with increased renal gene expresion of Nf-kB, TNF- and IL-6, which is consistent with previous reports [71,72]. SeNPs administration significantly and dose-dependently prevented an upregulation in cytokine response in CD-intoxicated mice, while selenite $\left(2 \mathrm{mg} \mathrm{kg}^{-1}\right.$ diet to chickens) has the ability to decrease the expression of blood proinflammatory factors (NF-KB and COX-2) that were upregulated following Cd exposure [73]. 

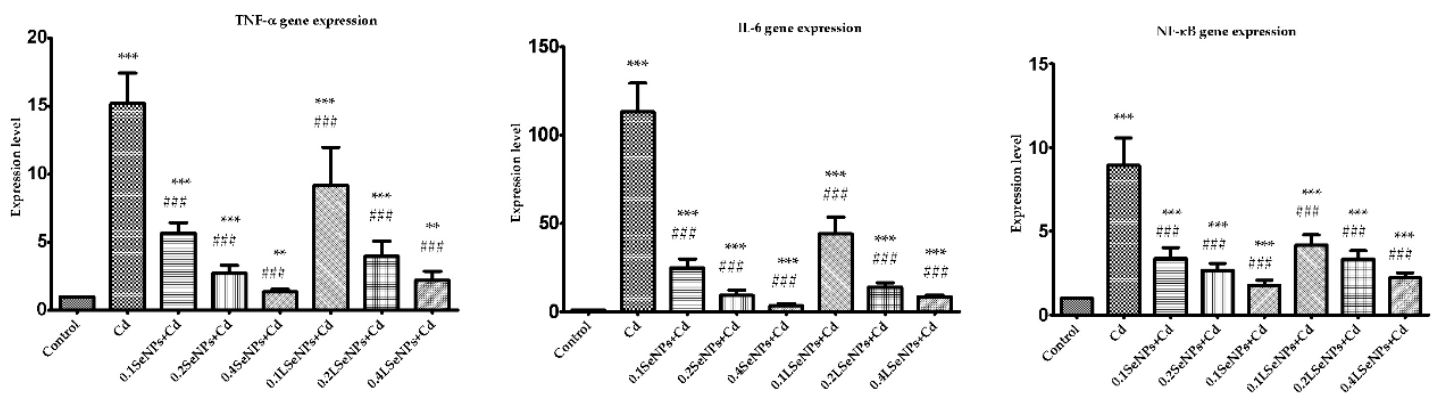

Figure 6. Renal TNF- $\alpha$, IL-6, NF-kB gene expressions. Groups: Control-mice received only water; Cadmium group (Cd)mice received orally $5 \mathrm{mg} / \mathrm{kg} \mathrm{CdCl} 2 ; 0.1 \mathrm{SeNPs}+\mathrm{Cd}(0.1 \mathrm{mg} / \mathrm{kg} \mathrm{SeNPs}+5 \mathrm{mg} / \mathrm{kg} \mathrm{CdCl} 2) ; 0.2 \mathrm{SeNPs}+\mathrm{Cd}(0.2 \mathrm{mg} / \mathrm{kg}$ SeNPs $+5 \mathrm{mg} / \mathrm{kg} \mathrm{CdCl} 2) ; 0.4 \mathrm{SeNPs}+\mathrm{Cd}(0.4 \mathrm{mg} / \mathrm{kg}$ SeNPs $+5 \mathrm{mg} / \mathrm{kg} \mathrm{CdCl}) ; 0.1 \mathrm{LSeNPs}+\mathrm{Cd}(0.1 \mathrm{mg} / \mathrm{kg} \mathrm{LSeNPs}+$ $5 \mathrm{mg} / \mathrm{kg} \mathrm{CdCl} 2) ; 0.2 \mathrm{LSeNPs}+\mathrm{Cd}(0.2 \mathrm{mg} / \mathrm{kg} \mathrm{LSeNPs}+5 \mathrm{mg} / \mathrm{kg} \mathrm{CdCl} 2) ; 0.4 \mathrm{LSeNPs}+\mathrm{Cd}(0.4 \mathrm{mg} / \mathrm{kg} \mathrm{LSeNPs}+5 \mathrm{mg} / \mathrm{kg}$ $\mathrm{CdCl}_{2}$ ). Groups: SeNPs $+\mathrm{Cd}$ and LSeNPs $+\mathrm{Cd}$ at different concentration vs. control group: $* * 0.01$; ${ }^{* * *} p<0.001$. Groups: SeNPs + Cd and LSeNPs + Cd at different concentration vs. cadmium group $(\mathrm{Cd})$ : \#\#\# $p<0.001$.

\section{Conclusions}

Through our study, we validated a new strategy to mitigate the renal toxic effects of cadmium, involving a combination of lactic acid bacteria and SeNPs. To the best of our knowledge, this study is the first attempt to evaluate the protective effects of SeNPsenriched L. casei on in vivo kidneys damage induced by cadmium.

In our study, both selenium products (SeNPs and LSeNPs) have protective effect against $\mathrm{Cd}$ induced renal toxicity in dose-dependent manner. Probably, the better effect provided by LSeNPs is due to synergic activity of SeNPs and probiotic bacteria, being known that probiotic bacteria have good ability to bind Cd [18]. In conclusion, Se-enriched L. casei could provide a better alternative as a functional food due the double efficacy of Se and probiotics and to be further use to protect against $\mathrm{Cd}$-induced kidneys toxicity.

Author Contributions: Conceptualization, A.H., S.I.V. and J.P.; methodology, S.I.V., V.L., A.V.T., C.B., H.H., A.C., S.G., M.R., B.M., L.F., S.C., A.H. and C.C.; formal analysis, S.I.V., V.L., A.V.T., C.B., H.H., A.C., S.G., M.R., B.M., L.F., S.C., C.C., C.P., M.P. and E.M.; resources, S.I.V. and A.H.; writing-review and editing, S.I.V., S.C. and A.H. All authors have read and agreed to the published version of the manuscript.

Funding: This research was funded by Romanian Ministry of Research and Innovation, project Number PN-III-P2-2.1-PED-2016-1846.

Institutional Review Board Statement: The study was conducted according to the guidelines of the Declaration of Helsinki and approved by the Ethics Committee of Vasile Goldis Western University of Arad (Certificate No. 71/07.06.2016).

Informed Consent Statement: Not applicable.

Data Availability Statement: The data presented in this study are available on request from the corresponding author. The data are not publicly available due to privacy.

Acknowledgments: The support of Traian Octavian Costea from University of Oradea for recording the AFM image is highly acknowledged.

Conflicts of Interest: The authors declare no conflict of interest.

\section{References}

1. Genchi, G.; Sinicropi, M.S.; Lauria, G.; Carocci, A.; Catalano, A. Review The Effects of Cadmium Toxicity. Int. J. Environ. Res. Public Health 2020, 17, 3782. [CrossRef]

2. Cai, K.; Yu, Y.; Zhang, M.; Kim, K. Concentration, Source, and Total Health Risks of Cadmium in Multiple Media in Densely Populated Areas, China. Int. J. Environ. Res. Public Health 2019, 16, 2269. [CrossRef] 
3. Xiao, R.; Guo, D.; Ali, A.; Mi, S.; Liu, T.; Ren, C.; Li, R.; Zhang, Z. Accumulation, Ecological-Health Risks Assessment, and Source Apportionment of Heavy Metals in Paddy Soils: A Case Study in Hanzhong, Shaanxi, China. Environ. Pollut. 2019, 248, 349-357. [CrossRef] [PubMed]

4. Rao, Z.X.; Huang, D.Y.; Wu, J.S.; Zhu, Q.H.; Zhu, H.-H.; Xu, C.; Xiong, J.; Wang, H.; Duan, M.M. Distribution and Availability of Cadmium in Profile and Aggregatesof a Paddy Soil with 30-Year Fertilization and Its Impact on Cd Accumulation in Rice Plant. Environ. Pollut. 2018, 239, 198-204. [CrossRef] [PubMed]

5. Daisley, B.A.; Monachese, M.; Trinder, M.; Bisanz, J.E.; Chmiel, J.A.; Burton, J.P.; Reid, G. Immobilization of Cadmium and Lead by Lactobacillus Rhamnosus GR-1 Mitigates Apical-Tobasolateral Heavy Metal Translocation in a Caco-2 Model of the Intestinal Epithelium. Gut. Microbes. 2019, 10, 321-333. [CrossRef] [PubMed]

6. Satarug, S. Dietary Cadmium Intake and Its Effects on Kidneys. Toxics 2018, 6, 15. [CrossRef]

7. Tinkov, A.A.; Gritsenko, V.A.; Skalnaya, M.G.; Cherkasov, S.V.; Aaseth, J.; Skalny, A.V. Gut as a Target for Cadmium Toxicity. Environ. Pollut. 2018, 235, 429-434. [CrossRef]

8. Arroyo, V.S.; Flores, K.M.; Ortiz, L.B.; Gómez-Quiroz, L.E.; Gutiérrez-Ruiz, M.C. Liver and Cadmium Toxicity. J. Drug. Metab. Toxicol. 2012, S5:001, 1-7. [CrossRef]

9. Flora, S.J.S.; Pachauri, V. Chelation in Metal Intoxication. Int. J. Environ. Res. Public Health 2010, 7, 2745-2788. [CrossRef] [PubMed]

10. Mandel, J.S.; McLaughlin, J.K.; Schlehofer, B.; Mellemgaard, A.; Helmuert, U.; Linbald, R.; McCredie, M.; Adami, U. International Renal-Cell Cancer Study. IV. Occupation. Int. J. Cancer 1995, 61, 601-605. [CrossRef]

11. Zalups, R.K.; Ahmad, S. Molecular Handling of Cadmium in Transporting Epithelia. Toxicol. Appl. Pharmacol. 2003, 186, 163-188. [CrossRef]

12. Klaassen, C.D.; Liu, J. Role of Metallothionein in Cadmium-Induced Hepatotoxicity and Nephrotoxicity. Drug. Metab. Rev. 1997, 29, 79-102. [CrossRef]

13. Cavalu, S.; Simon, V. Proteins Adsorption to Orthopedic Biomaterials-Vibrational Spectroscopic Evidence. J. Optoelectron. Adv. Mater. 2007, 9, 3297-3302.

14. Duan, H.; Yu, L.; Tian, F.; Zhai, Q.; Fan, L.; Chen, W. Gut Microbiota: A Target for Heavy Metal Toxicity and a Probiotic Protective Strategy Review. Sci. Total. Environ. 2020, 742, 140429. [CrossRef] [PubMed]

15. Inbaraj, B.S.; Chen, B.-H. In Vitro Removal of Toxic Heavy Metals by Poly( $\Upsilon$-Glutamic Acid)-Coated Superparamagnetic Nanoparticles. Int. J. Nanomed. 2012, 7, 4419-4432.

16. Xia, S.K.; Chen, L.; Liang, J.Q. Enriched Selenium and Its Effects on Growth and Biochemical Composition in Lactobacillus Bulgaricus. J. Agric. Food Chem. 2007, 55, 2413-2417. [CrossRef]

17. Elsanhoty, R.M.; Al-Turki, I.A.; Ramadan, M.F. Application of Lactic Acid Bacteria in Removing Heavy Metals and Aflatoxin B1 from Contaminated Water. Water Sci. Technol. 2016, 74, 625-638. [CrossRef] [PubMed]

18. Ibrahim, F.; Halttunen, T.; Tahvonen, R.; Salminen, S. Probiotic Bacteria as Potential Detoxification Tools: Assessing Their Heavy Metal Binding Isotherms. Can. J. Microbiol. 2016, 52, 877-885. [CrossRef] [PubMed]

19. Calomme, M.; Hu, J.; Van den Branden, K.; Vanden Berghe, D.A. Seleno-Lactobacillus. An Organic Selenium Source. Biol. Trace Elem. Res. 1995, 47, 379-383. [CrossRef] [PubMed]

20. Eszenyi, P.; Sztrik, A.; Babka, B.; Prokisch, J. Elemental, Nano-Sized (100-500 Nm) Selenium Production by Probiotic Lactic Acid Bacteria. Int. J. Biosci. Biochem. Bioinform. 2011, 1, 148-152. [CrossRef]

21. Eswayah, A.S.; Smith, T.J.; Gardiner, P.H.E. Microbial Transformations of Selenium Species of Relevance to Bioremediation. Appl. Environ. Microbiol. 2016, 82, 4848-4859. [CrossRef] [PubMed]

22. Prokisch, J.; Zommara, M. Process for Producing Elemental Selenium Nanospheres. U.S. Patent 20100189634,23 August 2011.

23. El-Boshy, M.E.; Risha, E.F.; Abdelhamid, F.M.; Mubarak, M.S.; Hadda, T.B. Protective Effects of Selenium against Cadmium Inducedhematological Disturbances, Immunosuppressive, Oxidative Stress Andhepatorenal Damage in Rats. JTEMB 2015, 29, 104-110. [CrossRef]

24. El-Ramady, H.R.; Domokos-Szabolcsy, É.; Abdalla, N.A.; Alshaal, T.A.; Shalaby, T.A.; Sztrik, A.; Prokisch, J.; Fári, M. Selenium and Nano-Selenium in Agroecosystems. Environ. Chem. Lett. 2014, 12, 495-510. [CrossRef]

25. Kieliszek, M.; Błażejak, S. Current Knowledge on the Importance of Selenium in Food for Living Organisms: A Review. Molecules 2016, 21, 609. [CrossRef]

26. Zwolak, I. The Role of Selenium in Arsenic and Cadmium Toxicity: An Updated Review of Scientific Literature. Biol. Trace Elem. Res. 2020, 193, 44-63. [CrossRef]

27. Rayman, M.P. The Use of High-Selenium Yeast to Raise Selenium Status: How Does It Measure Up? Br. J. Nutr. 2014, 92, 557-573. [CrossRef]

28. Ingale, A.G.; Chaudhari, A.N. Biogenic Synthesis of Nanoparticles and Potential Applications: An Eco-Friendly Approach. J. Nanomed. Nanotechnol. 2013, 4, 1-7. [CrossRef]

29. Chen, J.; He, W.; Zhu, X.; Yang, S.; Yu, T.; Ma, W. Epidemiological Study of Kidney Health in an Area with High Levels of Soil Cadmium and Selenium: Does Selenium Protect against Cadmium-Induced Kidney Injury? Sci. Total. Environ. 2020, 698, 134106. [CrossRef] [PubMed] 
30. Skröder, H.; Hawkesworth, S.; Kippler, M.; El Arifeen, S.; Wagatsuma, Y.; Moore, S.E.; Vahter, M. Kidney Function and Blood Pressure in Preschool-Aged Children Exposed to Cadmium and Arsenic_Potential Alleviation by Selenium. Environ. Res. 2015, 140, 205-213. [CrossRef] [PubMed]

31. Wei, X.L.; He, J.R.; Cen, Y.L.; Su, Y.; Chen, L.J.; Lin, Y.; Wu, B.H.; Su, F.X.; Tang, L.Y.; Ren, Z.F. Modified Effect of Urinary Cadmium on Breast Cancer Risk by Selenium. Clin. Chim. Acta 2015, 438, 80-85. [CrossRef] [PubMed]

32. Zhai, Q.; Tian, F.; Zhao, J.; Zhang, H.; Narbad, A.; Chen, W. Oral Administration of Probiotics Inhibits Absorption of the Heavy Metal Cadmium by Protecting the Intestinal Barrier. Appl. Environ. Microbiol. 2016, 82. [CrossRef]

33. Yang, J.; Hou, B.; Wang, J.; Tian, B.; Bi, J.; Wang, N.; Li, X.; Huang, X. Nanomaterials for the Removal of Heavy Metals from Wastewater. Nanomaterials 2019, 9, 424. [CrossRef] [PubMed]

34. Benko, I.; Nagy, G.; Tanczos, B.; Ungvari, E.; Sztrik, A.; Eszenyi, P.; Prokisch, J.; Banfalvi, G. Subacute Toxicity of Nano-Selenium Compared to Other Selenium Species in Mice. Environ. Toxicol. Chem. 2012, 31, 2812-2820. [CrossRef] [PubMed]

35. Ren, X.M.; Wang, G.G.; Xu, D.Q.; Luo, K.; Liu, Y.X.; Zhong, Y.H.; Cai, Y.Q. The Protection of Selenium on Cadmium-Induced Inhibition of Spermatogenesis via Activating Testosterone Synthesis in Mice. Food Chem. Toxicol. 2012, 50, 3521-3529. [CrossRef]

36. Re, R.; Pellegrini, N.; Proteggente, A.; Pannala, A.; Yang, M.; Rice-Evans, C. Antioxidant Activity Applying an Improved ABTS Radical Cation Decolorization Assay. Free Radic. Biol. Med. 1999, 26, 1231-1237. [CrossRef]

37. Livak, K.J.; Schmittgen, T.D. Analysis of Relative Gene Expression Data Using Real-Time Quantitative PCR and the 2(-Delta Delta C(T)) Method. Methods 2001, 25, 402-408. [CrossRef] [PubMed]

38. Cavalu, S.; Kamel, E.; Laslo, V.; Fritea, L.; Costea, T.; Antoniac, I.V.; Vasile, E.; Antoniac, A.; Semenescu, A.; Mohan, A.; et al. Eco-Friendly, Facile and Rapid Way for Synthesis of Selenium Nanoparticles. Production, Structural and Morphological Characterisation. Rev. Chim. 2018, 68, 2963-2966. [CrossRef]

39. Cavalu, S.; Antoniac, I.V.; Fritea, L.; Mates, I.M.; Milea, C.; Laslo, V.; Vicas, S.; Mohan, A. Surface Modifications of the Titanium Mesh for Cranioplasty Using Selenium Nanoparticles Coating. J. Adhes. Sci. Tech. 2018, 32, 2509-2522. [CrossRef]

40. Xu, C.; Guo, Y.; Qiao, L.; Ma, L.; Cheng, Y.; Roman, A. Biogenic Synthesis of Novel Functionalized Selenium Nanoparticles by Lactobacillus Casei ATCC 393 and Its Protective Effects on Intestinal Barrier Dysfunction Caused by Enterotoxigenic Escherichia Coli K88. Front. Microbiol. 2018, 9, 1129. [CrossRef]

41. Wallin, M.; Sallsten, G.; Lundh, T.; Barregard, L. Low-Level Cadmium Exposure and Effects on Kidney Function. Occup. Environ. Med. 2014, 71, 848-854. [CrossRef]

42. He, Y.; Chen, S.; Liu, Z.; Cheng, C.; Li, H.; Wang, M. Toxicity of Selenium Nanoparticles in Male Sprague-Dawley Rats at Supranutritional and Nonlethal Levels. Life Sci. 2014, 115, 44-51. [CrossRef] [PubMed]

43. Rubio, C.P.; Hernández-Ruiz, J.; Martinez-Subiela, S.; Tvarijonaviciute, A.; Ceron, J.J. Spectrophotometric Assays for Total Antioxidant Capacity (TAC) in Dog Serum: An Update. BMC Vet. Res. 2016, 12, 1-7. [CrossRef]

44. Katalinica, V.; Modun, D.; Music, I.; Boban, M. Gender Differences in Antioxidant Capacity of Rat Tissues Determined by 2,2V-Azinobis (3-Ethylbenzothiazoline 6-Sulfonate; ABTS) and Ferric Reducing Antioxidant Power (FRAP) Assays. Comp. Biochem. Physiol. Part C 2005, 140, 47-52. [CrossRef]

45. Ognjanovic, B.I.; Pavlovic, S.Z.; Maletic, S.D.; Zikic, R.V.; Stajn, A.S.; Radojicic, R.M.; Saicic, Z.S.; Petrovic, V.M. Protective Influence of Vitamin E on Antioxidant Defense System in the Blood of Rats Treated with Cadmium. Physiol. Res. 2003, 52, 563-570. [PubMed]

46. El-Sharaky, A.S.; Newairy, A.A.; Badreldeen, M.M.; Eweda, S.M.; Sheweita, S.A. Protective Role of Selenium against Renal Toxicity Induced by Cadmium in Rats. Toxicology 2007, 235, 185-193. [CrossRef]

47. Hasani, M.; Djalalinia, S.; Khazdooz, M.; Asayesh, H.; Zarei, M.; Gorabi, A.M.; Ansari, H.; Qorbani, M.; Heshmat, R. Effect of Selenium Supplementation on Antioxidant Markers: A Systematic Review and Meta-Analysis of Randomized Controlled Trials. Hormones 2019, 18, 451-462. [CrossRef] [PubMed]

48. Liu, J.; Habeebu, S.S.; Liu, Y.; Klaassen, C.D. Acute CdMT Injection Is Not a Good Model to Study Chronic Cd Nephropathy: Comparison of Chronic CdCl2 and CdMT Exposure with Acute CdMT Injection in Rats. Toxicol. Appl. Pharmacol. 1998, 153, 48-58. [CrossRef]

49. Thijssen, S.; Maringwa, J.; Faes, C.; Lambrichts, I.; Van Kerkhove, E. Chronic Exposure of Mice to Environmentally Relevant, Low Doses of Cadmium Leads to Early Renal Damage, Not Predicted by Blood or Urine Cadmium Levels. Toxicology 2007, 229, 145-156. [CrossRef]

50. Damek-Poprawa, M.; Sawicka-Kapusta, K. Damage to the Liver, Kidney, and Testis with Reference to Burden of Heavy Metals in Yellow-Necked Mice from Areas around Steelworks and Zinc Smelters in Poland. Toxicology 2003, 186, 1-10. [CrossRef]

51. Bernard, A.; Lauwerys, R. Early Markers of Cadmium Nephrotoxicity: Biological Significance and Predictive Value. Toxicol. Environ. Chem. 1990, 27, 65-72. [CrossRef]

52. Bernard, A. Biomarkers of Metal Toxicity in Population Studies: Research Potential and Interpretation Issues. J. Toxicol. Environ. Health A 2008, 71, 1259-1265. [CrossRef]

53. Park, J.D.; Cherrington, N.J.; Klaassen, C.D. Intestinal Absorption of Cadmium Is Associated with Divalent Metal Transporter 1 in Rats. Toxicol. Sci. 2002, 68, 288-294. [CrossRef]

54. Johri, N.; Jacquillet, G.; Unwin, R. Heavy Metal Poisoning: The Effects of Cadmium on the Kidney. Biometals 2010, 23, 783-792. [CrossRef] 
55. Chen, L.; Lei, L.; Jin, T.; Nordberg, M.; Nordberg, G.F. Plasma Metallothionein Antibody, Urinary Cadmium, and Renal Dysfunction in a Chinese Type 2 Diabetic Population. Diabetes Care 2006, 29, 2682-2687. [CrossRef]

56. Gan, L.; Liu, Q.; Xu, H.B.; Zhu, Y.S.; Yang, X.L. Effects of Selenium Overexposure on Glutathione Peroxidase and Thioredoxin Reductase Gene Expressions and Activities. Biol. Trace Elem. Res. 2002, 89, 165-175. [CrossRef]

57. Verzola, D.; Bertolotto, M.B.; Villaggio, B.; Ottonello, L.; Dallegri, F.; Frumento, G.; Berruti, V.; Gandolfo, M.T.; Garibotto, G.; Deferran, G. Taurine Prevents Apoptosis Induced by High Glucose in Human Tuble Renal Cells. J. Investig. Med. 2002, 50, $443-451$. [CrossRef]

58. Messner, B.; Turkcan, A.; Ploner, C.; Laufer, G.; Bernhard, D. Cadmium Overkill: Autophagy, Apoptosis and Necrosis Signalling in Endothelial Cells Exposed to Cadmium. Cell. Mol. Life Sci. 2016, 73, 1699-1713. [CrossRef]

59. Oltval, Z.N.; Milliman, C.L. Korsmeyer SJ Bcl-2 Heterodimerizes in Vivo with a Conserved Homolog, Bax, that Accelerates Programed Cell Death. Cell 1993, 74, 609-619. [CrossRef]

60. Kinne-Saffran, E.; Hulseweh, M.; Pfaff, C.; Kinne, R.K. Inhibition of Na, K-ATPase by Cadmium: Different Mechanisms in Different Species. Toxicol. Appl. Pharmacol. 1993, 121, 22-29. [CrossRef]

61. Wang, Y.; Fang, J.; Leonard, S.S.; Rao, K.M. Cadmium Inhibits the Electron Transfer Chain and Induces Reactive Oxygen Species. Free Radic. Biol. Med. 2004, 36, 1434-1443. [CrossRef]

62. Stohs, S.J.; Bagchi, D.; Hassoun, E.; Bagchi, M. Oxidative Mechanisms in the Toxicity of Chromium and Cadmium Ions. J. Environ. Pathol. Toxicol. Oncol. 2000, 19, 201-213. [CrossRef] [PubMed]

63. Tang, W.; Shaikh, Z.A. Renal Cortical Mitochondrial Dysfunction upon Cadmium Metallothionein Administration to SpragueDawley Rats. J. Toxicol. Environ. Health A 2001, 63, 221-235. [CrossRef] [PubMed]

64. Thevenod, F. Nephrotoxicity and the Proximal Tubules. Insights from Cadmium. Nephron Physiol. 2003, 93, 87-93. [CrossRef]

65. Desagher, S.; Martinou, J.C. Mitochondria as the Central Control Point of Apoptosis. Trends. Cell. Biol. 2000, 10, 369-377. [CrossRef]

66. Thévenod, F.; Friedmann, J.M.; Katsen, A.D.; Hauser, I.A. Up-Regulation of Multidrug Resistance P-Glycoprotein via Nuclear Factor-KappaB Activation Protects Kidney Proximal Tubule Cells from Cadmium- and Reactive Oxygen Species-Induced Apoptosis. J. Biol. Chem. 2000, 275, 1887-1896. [CrossRef]

67. Tzirogiannis, K.N.; Panoutsopoulos, G.I.; Demonakou, M.D.; Hereti, R.I.; Alexandropoulou, K.M.; Basayannis, A.C.; Mykoniatis, M.G. Time-Course of Cadmium-Induced Acute Hepatotoxicity in the Rat Liver: The Role of Apoptosis. Arch. Toxicol. 2003, 77, 694-701. [CrossRef] [PubMed]

68. Wang, Y.; Wu, Y.; Luo, K.; Liu, Y.; Zhou, M.; Yan, S.; Shi, H.; Cai, Y. The Protective Effects of Selenium on Cadmium-Induced Oxidative Stress and Apoptosis via Mitochondria Pathway in Mice Kidney. Food Chem. Toxicol. 2013, 58, 61-67. [CrossRef]

69. Kayama, F.; Yoshida, T.; Elwell, M.R.; Luster, M.I. Cadmium-Induced Renal Damage and Proinflammatory Cytokines: Possible Role of IL-6 in Tubular Epithelial Cell Regeneration. Toxicol. Appl. Pharmacol. 1995, 134, 26-34. [CrossRef]

70. Shaikh, Z.A.; Vu, T.; Zaman, K. Oxidative Stress as a Mechanism of Chronic Cadmium Hepatotoxicity and Nephrotoxicity and Protection by Antioxidants. Toxicol. Appl. Pharmacol. 1999, 154, 256-263. [CrossRef]

71. Kataranovski, M.; Kataranovski, D.; Savic, D.; Jovcic, G.; Bogdanovic, Z.; Jovanovic, T. Granulocyte and Plasma Cytokine Activity in Acute Cadmium Intoxicationin Rats. Physiol. Res. 1998, 47, 453-461.

72. Kataranovski, M.; Popovic, S.; Kataranovski, D. Differential Effects of in Vivocadmium Administration on Lymphocytes and Granulocytes in Rats. Vet. Hum. Toxicol. 1999, 41, 200-204.

73. Tan, S.; Chi, Q.; Liu, T.; Sun, Z.; Min, Y.; Zhang, Z.; Li, S. Alleviation Mechanisms of Selenium on Cadmium-Spiked Neutrophil Injury to Chicken. Biol. Trace Elem. Res. 2017, 178, 301-309. [CrossRef] 